\title{
Grabbing Land, Catching Votes! Land and the 2015 Election Campaign in Kilombero District, Tanzania
}

\section{Adriana Blache}

\section{(2) OpenEdition}

12 Journals

\section{Electronic version}

URL: https://journals.openedition.org/eastafrica/791

DOI: 10.4000/eastafrica.791

ISSN: 2790-1076

\section{Publisher}

IFRA - Institut Français de Recherche en Afrique

\section{Electronic reference}

Adriana Blache, "Grabbing Land, Catching Votes! Land and the 2015 Election Campaign in Kilombero District, Tanzania", Les Cahiers d'Afrique de l'Est / The East African Review [Online], 53 | 2019, Online since 07 January 2020, connection on 09 December 2021. URL: http://journals.openedition.org/ eastafrica/791 ; DOI: https://doi.org/10.4000/eastafrica.791

This text was automatically generated on 9 December 2021.

Les Cahiers d'Afrique de l'Est / The East African Review 


\title{
Grabbing Land, Catching Votes! Land and the 2015 Election Campaign in Kilombero District, Tanzania
}

\author{
Adriana Blache
}

\section{Introduction}

1 Throughout 2015, in every village of the Kilombero Valley in Tanzania, the general election generated fierce debates about livelihood, land and politics. In this internationally coveted valley of the Southern Agricultural Growth Corridor (SAGCOT), the election echoed nationwide debates about corruption, economic growth, poverty alleviation, infrastructure development and the growing power of the opposition. It also raised specific concerns over whether and how local development plans improve livelihood. During political meetings, village assemblies and even informal discussions in hoteli, ${ }^{1}$ future elected local government bodies continuously exploited the main local object of concern: land. In this highly desired space of the valley, the effects of the topdown SAGCOT initiative on local land politics can be analyzed through the campaign discourses relating to land investments and land access. These discourses were used by local elites as a strategy to maintain positions, expand socio-political power among villagers, prompt mobilization for resistance, or garner votes. To counter specific criticism of the internationally and locally debated land grabbing issue, local elites and political party candidates used a plethora of discursive resources to enhance their selfdeclared objective of "carrying the voice of the people." They promised to involve villagers in the different steps of development projects by using a participatory and inclusive approach and securing land through legal demarcation and title deeds. These rhetorical tools went hand in hand with concrete strategies involving institutional and physical violence, or solidarity and cooperation at different scales. 
2 This article aims to understand how struggles for land access and control shape space and how election campaigns highlight the complexity and the heterogeneity of the social, political, and economic powers between villages and among villagers. I will first analyze how government leaders and candidates use land regulations and tools to maintain their authority over local politics. This will help understand their role in development planning and in the way village subdivisions can be used as a means of control by district and ward political agencies, especially during election times. This geographical approach to land tenure aims, more broadly, to highlight the link between control of the physical space and control of the social space, as well as between space and politics.

Thus, I look at the role of election as a singular event in the so-called "participatory" processes for negotiations on land transaction which are drawn up by international institutions yet always involve the local level in one way or another. Generally, research on land grabs has highlighted inequalities in accessing negotiations: women and young people are generally not involved in decision-making processes that are often conducted by "representatives of traditional authorities and some elders [who] participate in consultations" (Kraut 2014: 294). However, it should be noted that detailed studies of these processes and of the integration of villagers within publicprivate partnerships are still limited. In addition, the consequences these negotiations have on the restructuring of social bonds within communities and families, depending on the socio-geographical situations of the spaces where the investments occur, are not well known either. We will see how these "top-down" initiatives-especially upstream and during the elections-engender social differentiation, transform local representations, and create enmity among the wards. These processes are the result of leaders' discourses aimed at dividing the organization of any resistance and/or gaining new voters. On the other hand, some candidates organize collective action and resistance in support of people's desire to keep "their land." They may also resort to physical violence. Lastly, the article will address the reactions, strategies and, ultimately, voting behavior of local people. These vary according to different geographical locations or activities and the emergence of resistance committees, themselves riddled with deep socio-political tensions. These representations, in an "area of movement" (Haggett 1965), are not only related to the necessity of keeping a piece of "land" rather than a socio-political "space." They are also linked to the role and impact of people migrating from other already "grabbed" lands, or from urban areas, in search of new investments.

\section{There Is a Politics of Land because Land Is Political ${ }^{2}$}

\section{The Geography of Power}

4 At the national level, campaign discourses during Tanzania's 2015 general election did not necessarily center on land issues, even though John Magufuli, the presidential candidate of the party in power and former single party, Chama Cha Mapinduzi (CCM), repeatedly promised to "reclaim [unused] land [that] will be given to poor farmers and livestock keepers" (The Citizen 6 September 2015). After he was elected as the new president of the country, he further stated that "land reforms [were] needed for promoting incentives to the actual tiller of the land for the promotion of agricultural 
production" (The Citizen 28 November 2015). Agreeing with those who contest "the neocolonial land grabs" and with Kawe Member of Parliament (MP) Halima Mdee's declarations about land conflicts in the Boko area, ${ }^{3}$ the opposition candidate of the CHADEMA (Chama cha Demokrasia na Maendeleo), Edward Lowassa, also declared that foreign investors would be asked to work in partnership with local communities (The Citizen 8 September 2015; The Guardian 9 November 2015).

Interestingly, the Kilombero Valley villagers, who gathered to watch the national news on TV every evening in their village's hoteli, were more interested in what their ward ${ }^{4}$ candidates had to say about land than they were in what the presidential candidates had to say. This was because, more generally, ward representatives are "directly involved in local politics and can bring concrete changes" (Focus group Mofu, interviews Namwawala 08/2015). Elections at the ward level are closely linked to their everyday experience, that is, to the proximity and tangibility of power, as political promises are "more likely to happen" (Interview with G.N., Ihenga village, 08/2015) and to impact their lives. Indeed, during elections, the "social network, proximity [that the ward and MP candidates have] to the centers of power, the availability of certain government if not private resources are considerable advantages" ${ }^{5}$ (Martin 1988: 162) in gaining villagers' support. The party that a candidate represents is not the most relevant indication of voting behavior: villagers are quite likely to vote for an opposition candidate at ward level or as member of parliament, and for a ruling party candidate at national level. Support can vary between, for example, the kitongoji, ${ }^{6}$ village chairman and village committee elections-all of which happened in December 2014. In the villages of the valley, which were created mainly thanks to the growth of the railways during the Ujamaa period and are today threatened by loss of access to land, past and present land development policies vary significantly. During the election, political meetings reinforced existing power relations but also provided a forum in which people's concerns could be raised. In this article, I therefore consider that political events need to be addressed "not on the front of formal institutions, "but on that of actions that aim to maintain or modify the established order"' (Balandier 1995: ix), quoted by Martin 1988: $9^{7}$ ). Politics is the expression of symbols, performances, discourses and conceptual logic that stem from organizational, institutional, rules and systems of social norms. Politics is not the prerogative of the state, but it unfolds through the relational dynamics between several levels, from the local to the global and vice-versa, in ways that are conditioned by the spaces on which they are being built.

6 Starting from this premise, an exploration of land issues in the 2015 election campaign requires adopting an approach anchored in the "geography of power" (Raffestin \& Turco 1984) according to which "politics is built in space and space builds politics" 8 (Dulucq \& Soubias 2004: 9). This perspective embraces the general idea that "there is a politics of space because space is political" (Lefebvre 2000 [1974]). Indeed, societies have always built their socio-political organization on the resources they could exploit. Land is one of these: it is, to quote Karl Polanyi, "an element of nature (...) linked with the organizations based on family, neighborhood, job and belief-along with the tribe, the temple, the village, the guild and the church." (1983 [1944]: 254). In the geography of power, power is not seen as coming from the "top" but it flows at and from every scale and is inherent to social, economic, political, and cultural relations (Foucault 2001 [1977]). Power does not follow a "zero sum game" whose attributes would be acquired 
by the "dominants" over the "dominated" (Raffestin 1980). I link the conceptual framework of the geography of power to the perspective developed in political anthropology, and more specifically the anthropology of development (Balandier 1967; Bailey 1969; Long 1994; Olivier de Sardan 1995). This considers conflicts-but also cooperation-related to access to and control over the same coveted resources, land, as being part of a "political arena" (Olivier de Sardan 1995; 2004) made up of multiple actors, intertwined scales and competing dynamics. Lastly, as "particular politicaleconomic moment," elections and electioneering can shape and reveal power relationships concerned with land, which is one of the most coveted resources in East Africa (Rutten \& Owuor 2009; Médard 2008; Boone 2011). According to Catherine Boone, with regard to the 1992 Kenyan election, "election-time political effects of land-related tensions can be dramatic" (2011: 2). Indeed, candidates use land as a patronage resource to gain support, promising "to reward supporters with land rights and to revoke the land rights of non-supporters" (Ibid: $3^{10}$ ). These are part of the dramatic dynamics which this article will explore.

\section{Coveted Land in the Kilombero Valley}

7 Tanzania is one of the main countries affected by the so-called "farmland rush" or "land grab," which has been the subject of international debate since 2008. The phenomenon, as defined by the international institutions and a majority of researchers -bar a few exceptions ${ }^{11}$-would not cover land surfaces acquired before 2000. This suggests that it is a new phenomenon, yet grabbing land is rooted in a long process of land appropriation and concentration in Africa. Clearly, "it can rightly be asserted that this phenomenon was at the heart of the colonial enterprise in Africa, and has continued to define its post-colonial political and economic interactions with international capital (Richard et al. 2010). What is new, and has raised concerns among advocates for rural land rights, is the scale and pace of these acquisitions" (Mollel 2014: 112). Some authors characterize the land grabbing phenomenon in Tanzania mainly with reference to the reallocation of colonial estates to new investors (Charlery de la Masselière \& Racaud 2013). The Kilombero Valley, however, is a highly coveted space and has seen different types of land enclosures, encroachments or dispossessions at different scales of space and time, not only involving colonial estates. Recent investments have targeted either conservation areas or estates set up during colonial times or during Ujamaa Vijijini; these areas have been reallocated to major international actors (Sulle \& Nelson 2013; Kimaro \& Hieronimo 2014; Geenen \& Hönke 2014). The colonial estates which were abandoned by the colonizers or parastatal companies have been occupied and used by farmers and pastoralists who are referred to as "invaders" or "squatters" by government officials or new investors.

\section{The Land Enclosures in Kilombero}

8 In the Kilombero Valley, some estates were demarcated and established under the colonial regime before being nationalized in the 1960 s and then privatized in the late 1980s. For example, the Kilombero Sugar Company Ltd (KSCL) owns two 12-hectare sugar cane estates, one on either side of the Great Ruaha River in the north of the valley (Martiniello 2015; Sulle and Smalley 2015). The cultivation of sugar cane in the valley was introduced by the Asians in the 1930s. In August 1960, the plantation under 
the aegis of the erstwhile Dutch consul (Martiniello 2015: 7) was created, supported by colonial laws and financial instruments (Sprenger 1989; Beck 1964). In 1967, it was nationalized and in 1975 it was placed under the control of the Sugar Development Corporation (SUDECO ${ }^{12}$ ), financially supported by international institutions (the International Finance Corporation, the Commonwealth Development Corporation (CDC), the Standard Bank of East Africa, and the Netherlands Overseas Finance Company). In the 1960s-1970s, Ujamaa Vijijini led to the creation of several villages around the plantation (Huizer 1971). In 1997-1998, when structural adjustments programs were adopted, the government sold it to Illovo Group and ED\&F MAN British Commodity Trader Company who revived production and the out-grower scheme and expanded its area of control (Mwami 2011; Martiniello 2015).

In 1992, in the south-east of the Valley, in Ulanga District and in the west of Kilombero District, the CDC acquired 28,000 ha of land in compensation for the Tanzanian debt held by the CDC at that time. This investment covers 8,000 ha of teak on four different plantations and 20,000 ha of conservation area that serves as an environmental corridor between the Selous Game Reserve to the east and the Kilombero wetlands and Udzungwa National Park to the west. One of the four plantations is located near the Matundu Forest Reserve (part of the Kilombero Nature Reserve), to the west, on the "Ruipa site" near Namwawala village. Likewise, in the south-west of the valley, with the same "conservationist and reforestation" objectives, another large company is Green Resources Ltd, established under the Clean Development Mechanism with the support of the Norwegian embassy. This company bases its activities mainly on "plantations, carbon offsets, forest products and renewable energy [and has] 34,000 ha of land, with a further 120,000 ha in the process of acquisition" near Uchindile, straddling Kilombero District, Mufindi and Kilolo (SAGCOT 2012; 2013; Bond et al. 2012).

Other large-scale plantations were demarcated during Ujamaa Vijijini, such as the Mngeta Farm which was established in 1976 through a joint-venture with North Korea -The Korean-Tanzania Joint Agricultural Company (KOTACO), implemented in 1986 and abandoned in 1995 by the Korean partner (Oakland Institute 2015). In 2006, the Rufiji Basin Development Agency (RUBADA) set up a joint-venture with InfEnergy-part of Agrica Ltd, a British company registered in the Guernsey Island tax haven-to revive the paddy farm on 5,900 ha, with the support of international institutions such as the World Bank, the British Development Fund (DFID 2013), and Bill and Melinda Gates Foundation for the out-grower schemes and development aid for the surrounding villages.

11 Another plantation was demarcated by SUDECO during Ujamaa Vijijini (1974) on the socalled "Ruipa site," mentioned above, in order to cultivate sugar cane. This project was revived in 2005 and is now the focus of the SAGCOT project. In this article, I will mainly explore this case study, still under negotiation, as it can highlight the power relations that unfold during the decision-making process-giving detail about this complex situation later.

12 In the valley, the enclosures also concern conservation areas such as the Udzungwa National Park established in 1994, the Selous Game Reserve established in 1982, and the RAMSAR site set up on 796,735 ha in 2002. A total of $91.4 \%$ of the Kilombero District is thus covered by conservation areas (SAGCOT 2012). Since 1956, the Kilombero floodplain and peripheral areas of woodland have been designated as a Game Controlled Area (GCA) and since 2002 as a RAMSAR site. Since 2012, the Kilombero GCA 
has been managed by the Belgium Tanzania Corporation (BTC) and the European Union, in partnership with the SAGCOT for its environment component (BTC 2016), under the name KILORWEMP. A German company, AMBERO, is working with the BTC to define the borders of the GCA and create Wildlife Management Areas. These are zones within villages which will be reserved for tourist hunting and therefore not used by villagers.

13 Finally, large-scale investments do not target the historically controlled estates, but can affect spaces used by peasants, pastoralists, teachers, traders, and doctors who have been living there for more than fifty years, mainly with customary right of occupancy (CRO) granted by the local government. In October 2015, oil companies and Tata Petrodyne Swala Oil \& Gas Plc Tanzania signed a farm-out agreement for the exploitation of oil and gas on a surface area of up to 6,000 ha in the Kidatu basin, north of the valley. About 27,300 ha in the Kilombero Basin (the RAMSAR site in the center of the Valley) and Kilosa (in Kilosa Valley) were also surveyed (Swala Energy website). Furthermore, in 2009, to meet the growing demand for investment in agricultural land, the Tanzanian government put in place new economic strategies through the Kilimo Kwanza (Agriculture First) initiative under the Agricultural Sector Development Program (ASDP). At the African World Economic Forum (WEF) 2010, President Jakaya Kikwete decided to create a corridor of agricultural modernization, SAGCOT, which covers a third of the country. From Dar es Salaam to Tunduma, on the border with Zambia, the corridor represents a delineated space in a heavily irrigable area in which ecological and climate conditions would allow significant agricultural production that could be easily transported and exported through the port of Dar es Salaam or to other regions of the East African Community.

The Kilombero Valley is located within the Kilombero cluster, one of the six clusters of the SAGCOT. It is considered to be the country's breadbasket and is therefore one of the most coveted areas, as highlighted by the government project: "These nearly 800,000 hectares of flood plain are among the most valuable in Tanzania for large-scale paddy rice and sugarcane production due to seasonal flooding and potential for largescale irrigation schemes" (SAGCOT 2013: 27).

\section{Land Conflicts and Evictions}

Demographic growth rates are high in the Kilombero valley (117\% since 1988, 26\% since 2002 for a total population of 407,880 in 2012 according to the 2012 National Census). This growth is essentially due to high rates of immigration of pastoralists and agropastoralists since 2000 , as well as farmers, workers and investors attracted by new opportunities created by the large-scale plantations. In the valley, evictions and the mobility they create are rooted in a long history. Resettlement planning started in the 1940s under British colonial rule and continued during the Ujamaa Vijijini period.

Nowadays the valley is the focus of conflicts involving pastoralists and farmers. In a context of high demographic growth and an increase in mobility, where local demand for land is increasingly sensitive, the reallocations of estates to new international investors has led to new conflicts over land. In 2006, evictions of pastoralists and agropastoralists from Mbarali district, Mbeya region, following the privatization of rice farms, led to an increase in the arrival of people in the Morogoro region and especially in the Kilombero valley (Tenga et al. 2008; Maganga et al. 2009). Here, conflicts have 
significantly increased since the establishment of the Kilombero GCA in 2012. This site covers a total of 108 villages -72 villages in Kilombero and 36 villages in Ulanga (Siima et al. 2012: 134). According to the RAMSAR site agreement (2002), "the bulk of the estimated population is confined to a strip of 858,850 ha of mixed arable land, wetland and Miombo woodland. The only room for expansion is into the floodplain or southwest along the valley." According to the Legal and Human Rights Center (LHRC), the Kilombero GCA could involve 126 villages and remove access to arable land for more than 600,000 people in Kilombero and Ulanga districts (LHRC, interview with Godfrey Lwena, Namwawala ward councillor, 20-08-2015). Researchers reported killings, stealing of pastoralists' cattle, and revenge attacks that led to murders or the burning of yield crops. Pastoralists and farmers complain that the RAMSAR site enclosed 400,000 ha of grazing and farming lands. In 2012, police-patrolled operations used trucks to evict more than 200,000 cattle. Between 2012 and 2014, several altercations between policemen and pastoralists resulted in injuries and killings, notably in Chita ward (Kitabu 2012; Nindi et al. 2014; interviews with villagers Ifakara; IWGIA 2013). The RAMSAR site enclosure is an even more sensitive issue for the villages surrounding the newly established plantations. The recent renewed enclosure of 5,900 ha by the Kilombero Plantation Ltd, only exacerbated the scarcity of land created by the proximity of the RAMSAR site to the east and the Udzungwa and Lyondo escarpment forest to the west, and significantly increased local land conflicts.

The involvement of international financial institutions, agribusiness firms and national government agencies in the enclosure of large-scale plots of land is part of a complex and long-standing system of actors. Recent investments are one more factor to consider. They go hand in hand with a discourse on "development" aid in which the private investor is seen as a necessary social actor. The analysis of development projects within large-scale investments will now allow us to address the formation of a "local political arena" (Olivier de Sardan 1995) within which "local development brokers" (Bierchenk 1993) or "gatekeepers" (Ansom, et al. 2014; M’Bokolo 2004: 389; Peemans 2014) evolve.

\section{From Post-Colonial “Local Elites" to Post-Socialist Local Governments}

\section{Beyond any Historical Determinism: the Social Construction of Local Decision-Makers}

18 Numerous studies highlight the predominant role of national and local elites in land grabs, especially in the Great Lakes region and in East Africa (Wolford et al. 2013; Ansoms et al. 2014; Bernstein 1981). It is claimed that so-called "foreign investors" often collaborate with the "locals" or employ them in key positions at different stages of their investment programs, notably when negotiating land access with village authorities. However, the various waves of land grabs in the region have always involved numerous actors at global, regional, national and local levels. Indeed, "at various periods of the history, local African elites have used their status and power as well as their familiarity with the institutional and legal contexts to acquire large land concessions" (Claessens et al. 2014: 83). They are more likely to be able to navigate the 
complex institutional landscape and thus to "gain comparative advantages at the expense of poorer and less well-connected actors" (Ibid).

Bearing in mind the role of the "local elites" (Ansoms et al. 2014) in land grab processes, it is crucial to explore the history of their formation given that they "do not develop out of the blue. They are the product of local stories, and operate within networks" (Olivier de Sardan 1995: $161^{13}$ ). It is also necessary to define what we mean by "local elite" and the extent and limitations of this concept. The term "local elite" is often used to designate the "authority," representing those who have more financial, economic and socio-cultural capital than others, yet without describing how these individuals-and the group they may form-acquired this status, that is to say, in which situation and through which mechanisms they became such an "elite." They may also be referred to as "local development brokers" (Bierschenk et al. 2000), "gatekeepers," the "rich and powerful," or the "the powerful chiefly" (Martin 1988). All these terms refer to the category of those who generally dominate the decision-making process and the economic and political development of the villages. However, power is not necessarily in the hands of those who are recognized as "policymakers." It can also be acquired, controlled, or maintained by individuals, groups, or institutions in particular political, economic and cultural circumstances. These may be "traditional authorities," linked to national NGOs, community activists, wealthier farmers, entrepreneurs arriving from urban areas or other densely populated spaces in search of land or new activities to develop, highly educated people returning to their home village, church leaders, elders, etc.

In Tanzania, Martin showed how colonization led to regional and social imbalances, based upon ecological disparities and the specific interests of the colonial state. The policy changed in the mid-1950s, which saw an increase in official financial and technical support for commercial agriculture in Africa, widened the "gap between wealthier farmers and others" (Martin 1988: 187). Favoring the "'tractor farmers'; "these famous modernist peasants [were] dear to the heart of the colonial administration"14 (Ibid.: 187). These "modernist peasants" were already in a "better" position before the colonial period, being traditional chiefs and therefore in a position to increase their power. Based on a study carried out in 1969, Martin argues that social differentiation was mainly the result of the importance of non-agricultural resources and wages from public service jobs. Although agricultural and land resources were not directly linked to social differentiation, it is recognized that the other incomes generated by non-agricultural resources and wages from public service jobs were earned by the "wealthier colonial farmers"-sometimes considered as "colons righthand men" (Fanon 1961)-who could concentrate lands and enhance their economic capital while aiding the penetration of the colonial machine. Furthermore, British colonization through the Colonial office had already initiated a vast decentralization program, expressing in 1947 the desire to "develop an effective system of local government" (Calas 2006). In 1967, three years after independence, Julius Nyerere, advised by the Company MacInsey and Company Inc. (Kubala 1993, quoted by Calas 2006) developed a vast decentralization program and argued in favor of it in his book Decentralization (Nyerere 1972). After independence and the adoption of a single-party government supported by a cumbersome structured governmental system, a majority of the wealthier farmers took political positions. They used the political infrastructure and policies to "reap the benefits to access credit, agricultural inputs, land; initiating, 
despite the abolition of private property, enterprises of concentration" ${ }^{15}$ (Martin 1988: 187). Indeed, civil servants and permanent members of the party who were elected or nominated were supposed to control the redistribution and use of land in the villages. However, in order to maintain control over these resources, notables and wealthy farmers concluded alliances with local policymakers. On the other hand, inserting notable leaders in the circle of local government was a means through which local government members could have a direct influence over local resources and control local populations. Thus, they could channel their political opinions, thanks to the authority and socio-cultural capital held by the notables and the already established local clienteles and social network. It was further exacerbated "in 1967 [with] the creation of the Regional Development Fund [which] gave to the civil servants/ permanent [members of the party] the means to build networks capable of including clienteles patronized by notables." ${ }^{16}$ This privileged relationship between civil servants from the local government and the "wealthier farmers" benefitted both parties, assuring the social position of the farmers while allowing control over the rest of the population (Martin 1988: 220). According to Huizer (1971), indeed, "the wealthier farmers were found to exercise considerable control within the Ujamaa system, because they were in a position to transfer usufruct rights of lands to poorer peasants who, in exchange, had to serve the 'patron' in several ways. This included participating in communal work parties, but also in electing the 'patron' to key positions in the TANU branch or ten-house cell. This patron-client relationship encroached on the egalitarian ideas behind the Ujamaa programme. It was difficult, however, to introduce anything into the villages without the consent and support of the local elites" (Huizer 1971: 28-29). Finally, little by little, drawing on these alliances, the wealthier farmers entered politics, and some of them are still governing the villages today.

It is important to bear in mind that the dynamics at local level are still today governed by patronage, brokerage networks and factional rivalries involving external and local actors. During the electoral campaign, the different political brokerage networks in presence built up new nodes, while factional rivalries, competitions and alliances involved the district authorities and representatives of parastatal and foreign companies. A "cycle of factional struggles involving citizens, community leaders, administrative or appointed [or elected] political leaders" ${ }^{17}$ (Martin 1988: 223) forms a complex system of stakeholders, linking people in the villages to the highest level of government. This explains the coexistence of multiple centers of power, of different importance and jurisdiction that are "more or less articulated, hierarchical or competing, and often fall under successive historical sedimentation"18 (Olivier de Sardan 1995: 165).

\section{The Ruipa Site and the 2015 Elections Campaign}

To exemplify my argument, I will now describe the situation observed in the Ruipa site, located at the center of the Kilombero Valley. In 1976, SUDECO surveyed and demarcated 9,272.54 ha with a view to establishing a sugar cane plantation in the Ruipa Valley, close to the Kilombero River. However, 400 parastatal companies went bankrupt that year, so the plantation could not be set up at that time. As a consequence, the demarcated area was colonized by people arriving as part of the Ujamaa Vijijini program and the TAZARA railway development (Chachage 2010). The first village was Mofu; then Mbingu, Namwawala and Idete grew up along the railway. The only 
historical proof of the demarcation today is a map showing the blocks of the intended plantation. This area represents $62 \%$ of the affected villages. At the outset, the total project was divided into six blocks (A, B, C, D, E and F), but due to a significant population increase, SUDECO abandoned blocks $\mathrm{D}, \mathrm{E}$ and $\mathrm{F}$. The three remaining blocks represent: block A Kisegese: 863.53 ha; block B Namwawala \& Mofu: 6,032.55 ha and block C Mbingu \& Mofu: 2,376.46 ha. Namwawala and Mofu are the most affected villages, where "population is nearly 10,000 people each" (Kipobota et al. 2009). In 2005, the government and the SBT, through the district officers, wanted to reallocate "ownership" of the land to a private foreign investor, Illovo Group, which already controlled the Kilombero Sugar Cane plantation in Kidatu. In 2012, Illovo pulled out of the "multi-billion deal "due to endless conflicts" (Rugonzibwa 2012). Conflicts were intensified by the establishment of the RAMSAR site to the east and the expansion of the Matundu Forest Reserve to the north-west and of other already established plantations like the Mbingu Sisters farm in Mbingu (1,214 ha), the Mofu Farms Ltd (500 ha) in Ihenga hamlet, the Usafirishaji Mikoani Union debating ownership of a land area (1,500 ha) in Chiwachiwa, the KVTC sites of Ichima and Narabungu sites in the Matundu Forest Reserve close to Namwawala and Idete villages, and the Idete prison farm (6,000 ha).

The land was earmarked as "free land for investment." It was promoted during the Agribusiness Investment Forum held in Dar es Salaam in November 2012, as a final stage of "site preparation in order to promote and lease it to qualified investors" (SAGCOT 2012: 30). However, the current situation as observed during field work and reported by the villagers shows that the area is densely populated and the scarcity of land has led to severe local land conflicts. Interviews revealed that ownership of this land is not in the hands of the government, and the so-called participatory process required to acquire and allocate village lands is not respected. On the contrary, since 2005, several events highlighted the arbitrary exercise of power and the coercive nature of consultations with villagers. In 2008, the Village Land Use Plans for Namwawala, Mofu and Kisegese, proposed by the district authorities to the Villages Assemblies, show the area demarcated for the sugar cane plantation, under the names "uwekezaji" (investment) or "shamba la miwa" (sugar cane plantation). The Village Land Use Plan had to be agreed by the Village Assembly and fraudulent VA minutes were produced by the village leaders, using the names of dead people, children and foreigners in order to provide district authorities with the necessary documents (interviews in Idandu 30 July 2015; LHRC 2010; Bergius 2015). In Namwawala, during a Village Assembly on 31 January 2009, following the radio announcement by district authorities saying that villagers should prepare themselves for the upcoming valuation process, villagers, together with the acting village chairman, started to organize themselves as a resistance committee. Villagers in Mofu, Kisegese and Namwawala organized a committee to monitor the order, but district authorities prevented them from doing so; those "who would go against the national interest would be punished," they said through a national newspaper. The same has happened several times since then (Chachage 2010; interviews Godfrey Lwena, 08/2016). Several cases of corruption also occurred during the negotiation process, involving both village and district authorities. They resulted in case $\mathrm{N}^{\circ} 40 / 2012$ being brought before Tanzania's High Court. 


\section{The Land Transfer in the Political Struggle of the Campaign}

24 have been built up on the basis of the historical social networks existing in the different villages involved. In the oldest village, Mofu, there are six main families-which I will call $\mathrm{N}, \mathrm{C}, \mathrm{M}, \mathrm{K}, \mathrm{S}$, and $\mathrm{Mb}$-all the members of which are related. The local government was historically ruled by $\mathrm{N}$, the wealthiest family. In January 2010, the father was elected CCM ward chancellor and his son village chairman. Ever since the colonial era, when the men were traditional chiefs of the villages, members of the $\mathrm{N}$ family have increased their influence and consolidated their power by acquiring large plots of lands, marrying several wives, expanding their "control area" and accumulating sociopolitical and economic capital. Interestingly, all the prominent families who gained power are related; the CHADEMA candidate from the $\mathrm{C}$ family, for example, also told us that the previous ward chancellor from CCM was his uncle. During the 2015 campaign, some people said that "those people know how to make money, so if we elect them, they will redistribute it to us, they will bring development in Mofu." Opponents, however, insisted that "things have to change, we don't want this family governing us anymore, it's like a monarchy" (interviews with Mofu villagers, 23 August 2015). During the campaign, the $\mathrm{N}$ son was candidate for the ward election and was in favor of a new investment, which could bring "development," "money" and new opportunities to Mofu village. In Namwawala village, newcomers who were running businesses wanted the investment in the Rupia site to be successful because it would bring more clients, new roads, electricity and market access. But claims to retain access to the land area in question could also come from wealthier farmers: in Namwawala, Godfrey Lwena, the ward candidate for CHADEMA, was the only person to have an official title deed for one of his plots, where he resides. His father, Joachim Lwena, was the village chairperson from 2000 to 2004 and has been a resident of the area since 1971. He possesses several plots and his son is also a representative of the Namwawala resistance committee.

In the Ruipa site, "the pluralistic configuration of interests" (Ansoms et al. 2014) highlighted during the campaign reflects a number of different factors, including the amount of land held and its localization, the main socio-economic activity, the link with political administrators, or the time spent in this area. Voting intentions varied according to the issues at stake: the farmers, pastoralists and agro-pastoralists who live on the project area in Myomboni (former hamlet of Mofu) and Idandu (former hamlet of Namwawala) were calling for official right of occupancy and legal recognition of their village. They were pushing candidates to give priority to the land issue, judging the future elected bodies or individuals in terms of their sincerity and power. Even within the same political party, candidates could disagree on the issue of future investment in the Rupia site. Those who lived on the coveted land fought to raise this issue during the campaign while others were keen to welcome the investment. Tensions were visible even during the primaries organized to select the candidate. The CCM in Namwawala ward did not select the candidate who was living in the planned area, Mr. S, who was also a member of the resistance committee. On the contrary, they voted for a candidate who lived in Ifakara, far from the planned area. During the electoral campaign meetings held in the villages, as well as in hoteli discussions and street-corner talks, villagers repeatedly debated local practices of cronyism. For instance, one day, in a hoteli in the center of Namwawala, women shouted at Mr. C, who had just been chosen as the CCM candidate. They argued that "he is for the investment 
because he has no land there." Indeed, Mr. C, also the former Ward Executive Officer, had promoted inward investment in the Rupia site since 2000. Nevertheless, due to the popularity of the CHADEMA candidate in Namwawala, the CCM candidate had to change his position and promised that villagers' land rights would be secured.

\section{About "Modernization" and "Development"}

Election campaigns bring to light political patronage networks as well as nepotism and clientelism both through discourse and practice. Those who want to gain power make rhetorical use of future development plans to control both the space and the social network that is built on it and that shapes it. The promised "development" is often topdown, designed and developed by international funding agencies, public and private institutions, companies and pension funds. Indeed, since colonization, the ideology of development has historically been adapted-in discourses and practices-from the international level to the local socio-economic level for the expansion of capitalism. Therefore, "we must reiterate that the principles of development have strengthened the administrative and technical coercion of the rural world. (...) The ideology of development deals with nature, space and society. The main idea is that nature is a given capital (the famous 'natural resources'); forgetting that this 'nature' is or was already ordered, mediated and socialized in the organization of native societies"19 (Charlery de la Masselière 2014: 42). In Tanzania, from the colonial period and the Ujamaa Vijijini program after the Arusha declaration to the Iringa declaration in 1974 and now the new Kilimo Kwanza initiative, many "development" plans have linked together land and agriculture, having a structuring effect on both landscapes and local governance practices. After the economic crisis of the late 1970s and early 1980s, the implementation of the three-year Economic Recovery Plan drawn up by the IMF and the World Bank was a milestone in the development of the country's agricultural and land policies. In 1997, the government created the Tanzania Investment Act No. 26 and established the Tanzania Investment Center (ICT) to "coordinate, promote, facilitate and encourage investment in Tanzania" (ICT 1997). Then, in 1999, Vision 2025 established a development program for the long term, in particular with the implementation of the initiative Mkakati wa Kukuza Uchumi Na Kupunguza Umaskini Tanzania (MKUKUTA) - the National Strategy for Growth and Reduction of Poverty (URT 2005).

As part of MKUKUTA, Kilimo Kwanza was set up in 2009 with the objective of giving agriculture a central role in the Tanzanian economy in order to promote the country's growth and development. To attract investors, the government has actively promoted private investment and facilitated it through the TIC and the Tanzania Investment Act of 1999. The SAGCOT gives priority to foreign investors: "strengthening the private sector in the country is one of our priorities" (Mary Michael Nagu, Minister of State for Investment \& Empowerment, 2015). Furthermore, to counter the recent worldwide criticisms of "land grabbing," the government stipules that: "Tanzania does not discriminate against businesses conducted or owned by foreign investors. It has no recent history of expropriation or nationalization" (SAGCOT 2012). The first official objective of the government through the SAGCOT is to link smallholder farmers with agribusiness "to improve agricultural productivity and increase rural incomes and employment opportunities” (SAGCOT 2013). 

villagers were not familiar with this program and even district officials had only heard about it. It is seen as a "top-down," non-inclusive and fairly obscure initiative. Nevertheless, everyone is aware that the valley and its development attract a great deal of attention, and plans for the establishment of large-scale farms are well known. Local elites use the discourse of the international organizations to implement top-down development projects, that is, to bring "development" through the necessary foreign investment, modernize Tanzanian agriculture by connecting small-scale farmers to the market, and set up estates and out-grower schemes. The investments planned for the Kilombero valley do not concern the enclosed space per se. The 2015 electoral campaign revealed that Corporate Social Responsibility (CSR) in development projects was at the heart of the candidates' promises. It highlights the importance of the "projectlanguage" (Olivier de Sardan 1988: 166), used by "modernist" notables and officials, who are ambitious, open to the outside world and interested in politics: thus, "they can talk together, they have a common language"20 (Martin 1988: 220).

Conceptions of foreign and wealthy investors are rooted in a long history. Some authors defined the Kilombero Sugar Cane Ltd plantation as a ' 'frontier area' (Cliffe 1977), characterized by the penetration and settlements of European (and other foreign) farmers, increased capitalist production methods, the ensuing need for labour, and the integration of smallholders within the circuit of agribusiness" (Martinielli 2015). Interestingly, on 22 October 2015, Prime Minister Mizengo Pinda held a conference with the Kilombero Sugar Plantation Ltd representatives. He congratulated the "residents of Kidatu and Kilombero [who] have been able to construct decent houses, run some auxiliary businesses, and most importantly take their children to school" (The Guardian 22 October 2015), thus highlighting the links between multiscalar political relations and agricultural development. Indeed, the out-grower schemes and jobs generated by the plantation had attracted new investors and new workers, creating a de facto land market and prompting demographic growth that has transformed urbanization dynamics.

The promises of what Prime Minister Pinda called "market-led development" were reappropriated and repeated by local ward candidates in different villages of the valley. They do not hesitate to exploit the promotion of investment to enhance their power and influence voting. Similarly, local politicians promise employment, development and better social services in the investment areas. However, field data from the 2015 election prove not only that these promises are never fulfilled, but that sometimes what happens is in fact the opposite of what was initially promised. In some places, the same people who had been eagerly waiting for employment not only end up never getting a job but are actually evicted from their land. Ariel Crozon revealed similar processes in the 1995 election, when CCM members and opposition party members were all engaged in "reckless promises to the peasants" (Crozon 1998: 164). In 2015, candidates promised to get rid of "irresponsible investors" and instead "recognize the rights of peasants and pastoralists on the land," while others promoted investment for "communication, social services (school, health services, employment for youth and women), and money."

31 By promising development through modernized agriculture as opposed to traditional and unproductive agriculture, the market-led ideology behind the SAGCOT program is accompanied by the dominant thinking on the availability of land in Tanzania, which 
highlights the abundance of "idle and unused lands." Since the colonial era, development models based on agricultural production have always postulated the need for effective demarcation to establish confined spaces and private property-with only partial recognition of customary rights. During the election campaign, meetings held to present the land targeted for investment to villagers focused on the two issues of legal recognition of ownership and the securing of land. In Mofu, Namwawala and Mbingu villages, wealthy farmers who did not fear any loss of land argued that those who had arrived after the demarcation in the 1980s were "illegal squatters" and "invaders" who should "go back to their land they were living on before" (Mofu focus group, 08/2015) and leave space for the new plantations. On the other hand, the inhabitants of the coveted lands also claimed legal recognition of ownership, based upon the customary right of occupancy (CROs) they had obtained from the village council. However, they were granted their CROs in controversial circumstances: the village chairpersons were said to have sold some plots to the newcomers illegally, since they were fully aware of the SUDECO demarcation. The superposition of different types of rights is materialized in the Village Land Use Plans in the villages concerned.

Mofu is the oldest village in the Ruipa site. Its inhabitants know the history of the planned SUDECO plantation of 1976 even though they had settled in the 1950s in an area that was not directly concerned by the project. During the last election, ward candidates and their supporters repeatedly promised development through land. A former village chairman explained: "Through the investments roads will be improved, social services improved (schools, health), employment and hence financial incomes for individuals and for the village in general, population will also increase as more people will come to look for jobs" (Mofu focus group, 08/2015). Taking as an example the KSCL plantation, the candidates also exploited the imagined abundance of capital, modernity and prosperity that investors would bring in. ${ }^{21}$ The former village chairman continued, insisting that investors could "use the money earned by selling sugar cane to buy rice for consumption purposes" (20 August 2015). According to him, villagers would benefit from cultivating sugar cane, seen as "more profitable and less labor-demanding than paddy" (Ibid.). Political candidates in favor of the plantation also talked up the benefits of infrastructure development and money circulation. For instance, the CCM candidate, a member of the wealthiest $\mathrm{N}$ family, drew a parallel with Mngeta where, he said, "even corporate responsibility is assured." He used expectations of "employment," "road construction and maintenance," and "electricity and water access" to promote the Rupia investment and simultaneously campaign for his political candidacy: "This is what will happen for us too, trust me" (CCM political meeting, Mofu village, August 2015). These promises resonate with those made in Mngeta in 2008. There, village representatives and district authorities had similarly promised that roads would be improved, electricity and water supplied, and land and new jobs made available for all thanks to the new company (interviews and focus groups, 8 August 2016). However, seven years later, as field work revealed, the main road had been cut off by the company, there is no electricity supply, water is polluted from the spraying of herbicides by airplane, and employment is mainly casual, for an average monthly salary of 150,000 Tsh (61€). In spite of this, today's candidates continue to use their ability to travel and establish business relationships out of the villages to create a picture of development based on large-scale agriculture. stronger in the hamlets directly targeted by the sugar cane project. These hamlets are 
principally composed of people who were evicted from the northern part of the Kilombero valley, especially from Msolwa Station-Magombiro hamlet-following the expansion of KSCL plantation in 1998. In 2002, some villagers moved to Idandu (Cha Moto, Michundani hamlets), Namwawala (Namwawala A, Kichongani hamlets) and Mofu (Miyomboni, Ihenga hamlets), all of which are located in the area concerned by the sugar cane project. These villagers related their experiences of the evictions and the increased capital inequalities in the villages surrounding the plantation. Interviewees spoke of "neocolonialism" and insisted that "development would only benefit the companies" (interviews in Idandu, Kirukutu and Kichongani hamlets, 08/2015). They mentioned a number of challenges they had had to face since the privatization, notably that they had been crowded onto less fertile land. Farmers did not want to be displaced again, qualifying themselves as "cattle, slaves in their own country" (focus group Idandu, 08/2015). It is no surprise that they made up the bulk of the resistance committee created in 2009. Denouncing government corruption at multiple levels, they blamed investors for their "irresponsibility," employing the same terms as those used in official discourses and taking as examples what happened in Kidatu and Mngeta. Opponents were also pastoralists and agro-pastoralists, mainly the Sukuma, originally from Shinyanga, Mwanza, Simyu and Mara regions. Following the privatization of a rice plantation in the Uanga plain of Mbarali district in Mbeya region (Matee and Shem 2006), they were evicted and migrated into the valley. They came to Morogoro region on the advice of the former Regional Commissioner, Mr. Steven Mashishanga, himself a Sukuma. The evictions of 2012-2014 in the Kilombero Valley have not been forgotten and people mistrust or are tired of the ruling party. During the 2015 campaign, the opponents and resistance committee members proved to be very influential; they were able to mobilize villagers and influence political party members. They could also help a candidate by persuading voters to vote for him or her. The candidates, always in need of more support, had as a result to adapt their discourse to please their potential electors.

\section{Conclusion}

After Tanzania's October 2015 general election, the three wards of the Kilombero valley located on the sugar cane plantation project switched from the ruling CCM to the opposition party CHADEMA. The two constituencies of Ifakara and Mlimba in Kilombero District, which is part of historically CCM-ruled Morogoro Region, were also won by the CHADEMA. This opposition win reflected dissatisfaction with the ruling party and its local elites, notably with the way they had managed land at the local level for decades. The electoral process itself was highly tense in the whole district. The main reasons given by the villagers interviewed in different areas of the district were lack of development (lack of electricity while the district provides the whole Morogoro region with the Kihansi Hydropower plant; lack of tarmac roads and water access) but also evictions and land enclosures. Another factor cited was high immigration rates and demographic mobility. In Ifakara, the district capital city, press releases highlighted aggressive and sometimes destructive behaviors during voting day: "37 people allegedly stormed the voting centre, set fire to government buildings and destroyed a district council motor vehicle" (Daily News 29 October 2015). 
Finally, the 2015 campaign brought to the fore issues of access to and control over land and made it possible to understand how the struggles for land significantly shape space. We have seen that these struggles for land are not new; they are rooted in a long history of land conflicts and appropriations. The election highlighted those tensions, revealing the complex and unstable webs of power relations between different actors at different geographical and institutional scales who are involved in the access to and the maintenance and control of land. Local elites and wards candidates used the existing institutional land governance framework either to empower villagers and help them retain access to land or to facilitate the planned investments through coercive consultancy. The election also had an impact on land negotiations and allocation. The High Court case was postponed during the election, but more than one year on it was still pending. One consequence of this is that the Land Tenure Support Programme (LTSP), initiated by the elected president John Magufuli on 18 February 2016 and financed by DFID, SIDA (Sweden aid) and DANIDA (Denmark aid), cannot be implemented in the villages concerned by the case until the judgment is handed down. Paradoxically, Kilombero, Ulanga and Malinyi districts in the Kilombero valley are the three pilot districts at the national level. Large-scale enclosures have always created conflicts, but with the new LTSP, the SAGCOT, the prohibited access to the Kilombero Game Controlled Area and the expansion of the forest reserve, conflicts over land and the dynamics of power relationships will undoubtedly continue well beyond the election year.

\section{BIBLIOGRAPHY}

Ansoms, An, and Thea Hilhorst, eds. 2014. Losing your Land: Dispossession in the Great Lakes. Woodbridge: James Currey.

Bailey, Frederick George. 1969. Stratagems and Spoils: a Social Anthropology of Politics. Oxford: Basil Blackwell.

Balandier, Georges. 1967. Anthropologie politique. Paris: Presses Universitaires de France.

Beck, A.D. 1964. “The Kilombero Valley of South-Central Tanganyika.” East Africa Geographical

Review, no. 2 (April): 37-43.

Bernstein, Henri. 1981. "Notes on the State and Peasantry: The Tanzanian Case." Review of African Political Economy, no. 21 (May-Sep.): 44-62.

Bierschenk, Thomas, Jean-Pierre Chauveau et Jean-Pierre Olivier de Sardan, eds. 2000. Courtiers en développement, les villages africains en quête de projets. Paris: Mayence, APAD, Institut für Ethnologie, J. Gutemberg Universität/Karthala.

Bond, Patrick, Khadja Sharife, Ruth Castel-Branco, eds. 2012. "The CDM Cannot Deliver the Money to Africa. Why the Clean Development Mechanism Won't Save the Planet from Climate Change, and How African Civil Society is Resisting." EJOLT Report no. 2. 
Boone, Catherine. 2011. "Politically Allocated Land Rights and the Geography of Electoral Violence: The Case of Kenya in the 1990s." Comparative Political Studies 44 (10): 1-32.

Boone, Catherine. 2015. "Land Tenure Regimes and State Structure in Rural Africa: Implications for Forms of Resistance to Large-scale Land Acquisitions by Outsiders." Journal of Contemporary African Studies 33 (2): 171-190.

Wolford Wendy, Saturnino M.J.R. Borras., Ruth Hall, Ian Scoones and Ben White. 2013. "Governing Global Land Deals: The Role of the State in the Rush for Land." Development and Change 44 (2): 189-210.

Chachage, Chambi. 2010. "Land Acquisition and Accumulation in Tanzania: The Case of Morogoro, Iringa and Pwani Regions.” Research Commissioned for Pelum Tanzania, (Oct.).

Charlery de la Masselière, Bernard and Sylvain Racaud. 2012. "De la terre patrimoine à la terre ressource en Afrique de l'Est." In Terres et tension en Afrique, edited by F. Bart: 399-412. Paris: Bulletin de l'Association des Géographes Français, (Sept.). https://www.persee.fr/doc/ bagf_0004-5322_2012_num_89_3_8277.

Charlery de la Masselière, Bernard. 2014. Penser la question paysanne en Afrique intertropicale. Toulouse: Presses Universitaires du Mirail.

Choukry, Hmed. 2009. "Espaces géographiques et mouvements sociaux." In Dictionnaire des mouvements sociaux, edited by Olivier Fillieule, Lilian Mathieu and Cécile Péchu: 220-227. Paris: Les Presses de Sciences po.

Claessens, Klara, Emery Mudinga and An Ansoms. 2014. "Competition Over Soil and Subsoil: Land Grabbing by Local Elites in South Kivu (Eastern DRC)." In Losing your Land: Dispossession in the Great Lakes, edited by Ansoms, An and Thea Hilhorst, 82-102. Woodbridge: James Currey.

Cliffe, Lionel. 1967. One Party Democracy, The 1965 Tanzania General Elections. Nairobi: East African Publishing House.

Coulson, Andrew. 1975. "Peasants and bureaucrats." Review of African Political Economy, no. 3 (MayOct.): 55-58.

Crozon, Ariel. 1998. "Dire pour séduire: langages et politique en Tanzanie." In Nouveaux langages du politique en Afrique orientale, edited by Martin Denis-Constant, 115-185. Paris: Karthala.

Daily News. 2015. “Accept All Pool Results Gently.” Daily News, October 29, 2015. http:// www.dailynews.co.tz/index.php/editorial/43690-accept-all-poll-results-gently. [archive]

Dausen, Nuzulack and Katare Mbashiru. 2015. "Magufuli Promises to Give Land to Herders, Farmers." The Citizen, September 6, 2015. http://www.thecitizen.co.tz/News/Magufuli-promisesto-give-land-to-herders--farmers/-/1840406/2860304/-/y5vh8g/-/index.html [archive].

Dulucq, Sophie et Soubias Pierre. 2004. "Introduction." In L'espace et ses représentations en Afrique, édité par Dulucq, Sophie et Pierre Soubias, eds., 11-14, Paris: Karthala.

Fanon, Frantz. 1961. Les damnés de la terre. Paris: Maspero.

Foreign \& Commonwealth Office and Department for International Development. 2013. “Tanzania and the UK Forge New Partnership on Trade and Investment." https://www.gov.uk/ government/news/tanzania-and-uk-forge-new-partnership-on-trade-and-investment [archive].

Geenen, Sara and Jana Hönke. 2014. "Land Grabbing by Mining Companies: Local Contentions and State Reconfiguration in South-Kivu (DRC)." In Losing your Land: Dispossession in the Great Lakes, edited by Ansoms, An and Thea Hilhorst, 58-81. Woodbridge: James Currey. 
Greco, Elisa. 2015. "Local Politics of Land and The Restructuring of Rice Farming Areas: A Comparative Study of Tanzania and Uganda." LCSV Working Paper, no. 12: 1-37.

Huizer, Gerrit. 1971. "The Ujamaa village Programme in Tanzania: New forms of Rural Development." I.S.S. Occasional Paper $n^{\circ} 11: 1-34$.

Hyden, Goran and Colin Leys. 1972. "Elections and Politics in Single-Party Systems: The Case of Kenya and Tanzania." The British Journal of Political Science, 2 (4) (Oct.): 289-420.

IWGIA. 2013. "Forced Evictions of Pastoralists in Kilombero and Ulanga Districts in Mollel, Morogoro Region in Tanzania." IWGIA Brief, (June): 1-5.

Isaksson, Rebecca and Ida Sigte. 2009. "Allocation of Tanzanian Village Land to Foreign Investors: Conformity to Tanzania's Constitution and the African Charter on Human and Peoples' Rights." Umea: University of Umea.

Kitabu, Gerald. 2012. "Three Sides of Kilombero Evictions Drive: Rare Species, Cattle Burden, Foreign Investments." The Guardian, November 11.

Kimaro, Didas and Proches Hieronimo. 2014. "Land for Agriculture in Tanzania: Challenges and Opportunities." Journal of Land and Society 1 (1) (Dec.): 91-102.

Lefebvre, Henri. 2000 [1974]. La production de l'espace. Paris: Anthropos.

Long, Norman. 1994 "Du paradigme perdu au paradigme retrouvé ? Pour une sociologie du développement orientée vers les acteurs.” Bulletin de L'APAD, no. 7: 11-34.

Lugongo, Bernard. 2015. "Foreign Investors to Partner with Locals: Lowassa." The Citizen, September 8. http://www.thecitizen.co.tz/News/Foreign-investors-to-partner-with-locals-Lowassa/-/1840406/2862598/-/436g6d/-/index.html [archive]

Luhwaga, Rodgers. 2012. "Land Motion Sparks Hot Debates in House." The Guardian, November 9. http://www.ippmedia.com/frontend/index.php?l=47812 [archive]

Martin, Denis-Constant. 1988. Tanzanie: l'invention d'une culture politique. Paris: Presses de la fondation nationale des sciences politiques \& Karthala.

Martiniello, Giuseppe. 2015. "Don't Stop the Mill": South African Sugar, Agrarian Change and Outgrowers Adverse Incorporation in the Kilombero Valley, Tanzania." BICAS Working Paper.

M’Bokolo, Elikia. 2004. Afrique noire. Histoire et civilisations. Du XIXe siècle à nos jours. Paris: Hatier/ AUF.

Médard, Claire. 2008. "Elected Leaders, Militias and Prophets." Les Cahiers d'Afrique de l'Est, Special issue, no. 38 (May-August): 349-374. https://journals.openedition.org/eastafrica/749

Migereko, Daudi. 2015. "NRM Does Not Condone Land Grabbing." New Vision, November 13. https://www.newvision.co.ug/new_vision/news/1412063/nrm-condone-land-grabbing [archive].

Mollel, Andrew. 2014. "Commercialisation of Land and Land Grabbing in Africa: Implications on Pastoralists Land Rights in Tanzania." Journal of Land and Society, 1 (1) (Dec.): 103-116.

Morgenthau, Ruth Schachter. 1965. “African Elections: Tanzania's Contribution.” Africa Report no. 10-11: 12-16.

Mtanda Juma. 2016. "Opposition cries foul as CCM Wins Kilombero Chair.” The Citizen, March 2. http://www.thecitizen.co.tz/News/Opposition-cries-foul-as-CCM-wins-Kilombero-chair/-/ 1840406/3099516/-/9tykkkz/-/index.html [archive] 
Mugerwa, Francis. 2016. “Besigye to Industrialise Uganda, Stop Land Grabbing." Daily Monitor, January 25. http://www.monitor.co.ug/SpecialReports/Elections/Besigye-to-industrialiseUganda--stop-land-grabbing/-/859108/3047692/-/njwjb1z/-/index.html [archive].

Mutahaba, Gelase. 1974. "Local Autonomy and National Planning: Complementary or Otherwise? Case Study from Tanzania." The African Review 4 (4): 508-530.

Mwami, Abunuwasi. 2011. "Land Grabbing in a Post Investment Period and Popular Reactions in the Rufiji River Basin." Research Report, HakiHardi, Occasional Paper no. 3: 1-44.

Nindi, Stephen Justice, Hanori Maliti, Samwel Bakari, Hamza Kija and Mwita Machoke. 2014. "Conflicts Over Land and Water Resources in The Kilombero Valley Floodplain, Tanzania." African Study Monography, no. 50: 173-190.

Ndamugoba, Sunday. 2015. "Homes \& Property: President Magufuli We're in Dire Need of Land Reforms.” The Citizen, November 28. http://www.thecitizen.co.tz/magazine/-/ 1840564/2975766/-/v8njyl/-/index.html [archive].

Olivier de Sardan, Jean-Pierre. 1995. Anthropologie et développement : essai en socio-anthropologie du changement social. Paris: APAD-Karthala.

Olivier de Sardan, Jean-Pierre. 2004. "État, bureaucratie et gouvernance en Afrique de l'Ouest francophone. Un diagnostic empirique, une perspective historique." Politique africaine, no. 96: 139-162. https://doi.org/10.3917/polaf.096.0139

Olivier de Sardan, Jean-Pierre. 2008. La rigueur du qualitatif. Les contraintes empiriques de l'interprétation socio-anthropologique. Louvain: Academia Bruylant.

The Oakland Institute, Green Peace Africa and Global Justice Now. 2015. Irresponsible Investment: Agrica's Broken Development Model in Tanzania. Oakland (CA): Oakland Institute.

Peemans, Jean-Philippe. 2014. "Land Grabbing and Development History: The Congolese Experience." In Losing your Land: Dispossession in the Great Lakes, edited by Ansoms, An and Thea Hilhorst, 11-35. Woodbridge: James Currey.

Polanyi, Karl. 1983 [1944]. La grande transformation: Aux origines politiques et économiques de notre temps. Paris: Gallimard.

Raffestin, Claude. 1980. Pour une géographie du pouvoir. Paris: Librairies techniques.

Raffestin, Claude et Turco, Angelo. 1984. "Espace et pouvoir.” In Les concepts de la géographie humaine, edited by A. Bailly: 45-50. Paris: Armand Colin.

Ribot, Jesse C. and Nancy Lee Peluso. 2003. “A Theory of Access.” Rural Sociology 68 (2): 153-181.

Rugonzibwa, Plus. 2012. “Tanzania: Kilombero Sugar project flops.” Daily News, January 23.

http://allafrica.com/stories/201201240459.html [archive].

Rutten, Marcel and Samuel Owuor. 2009. "Weapons of Mass Destruction: Land Ethnicity and the 2007 Elections in Kenya." Journal of Contemporary African Studies 27 (3): 305-24.

SAGCOT. 2012. SAGCOT Investment Partnership Program: Opportunities for Investors in the Sugar Sector.

Shivji, Issa G. 1998. Not Yet Democracy: Reforming Land Tenure in Tanzania. Dar es Salaam: IIED/ HakiArdhi/University of Dar es Salaam.

Siima, Bakengesa, Pantaleao K.T. Munishi, Yonika M. Ngaga and Stale Navrud. 2012. "Estimating Direct Use Value of Kilombero RAMSAR Site Based on Market Price Method.” Tanzania Journal of Forestry and Nature Conservation 81 (2) (December): 133-146. 
Sprenger, Ellen. 1988. Sugarcane Outgrowers and Kilombero Sugar Company in Tanzania. Nijmegen: Third World Centre.

Sulle, Emmanuel and Fred Nelson. 2009. Biofuels, Land Access and Rural Livelihoods in Tanzania. London: IIED.

Sulle, Emmanuel and Fred Nelson. 2012. "Land Grabbing and Political Transformation in Tanzania." Paper presented at the International Conference on Global Land Grabbing II, 17-10 October 2012.

Sulle, Emmanuel and Rebecca Smalley. 2015. "Study of Sugarcane Outgrowing at Kilombero." Futures Agricultures, PLAAS, May 2015.

URoT. 2013. Southern Agricultural Growth Corridor of Tanzania (SAGCOT) Investment Project: ReSettlement policy framework, Dar es Salaam: URoT (Sept.).

URoT. 2009. Local Government System in Tanzania. Dar es Salaam: URoT.

URoT, Tanzania Investment Center (TIC). 2015. Tanzania Investment Guide 2014-2015. Dar es Salaam: URoT.

\section{NOTES}

1. Hoteli means "restaurant" in Kiswahili.

2. Lefebvre 1974.

3. Kawe MP Halima Mdee is well known in Tanzania for arguing against land grabbing and for denouncing political bodies involved in illegal land investments. She has been an MP since 2005 and is a member of the CHADEMA Central committee as well as the Chairperson of CHADEMA Women's Wing at national level (www.parliament.go.tz/ administrations/31 [archive]). In 2014 she publicly accused the former Minister of Land, Housing and Settlements, Anna Tibaijuka, of fueling land conflicts through her ownership of large plots of lands (http://pesatimes.co.tz/news/legal-environment/ tibaijuka--halima-mdee-at-loggerheads/tanzania).

4. In Tanzania, the ward is the administrative level made up of at least three registered villages. In January 2015, several wards and villages of the Kilombero valley were divided. We will explain later how this subdivision, carried out just before the campaign, altered the local political dynamics.

5. My translation from French: “(...) son entregent, sa proximité des centres du pouvoir, la disponibilité de certaines ressources gouvernementales sinon même privées sont des atouts considérables" (Martin 1988: 162).

6. Hamlet in Kiswahili.

7. My translation from French: “(...) non sur le terrain des institutions formelles, mais sur 'celui des actions qui visent le maintien ou la modification de l'ordre établi' (Balandier 1995: ix)” (Martin 1988: 9).

8. My translation from French: "La politique se construit dans l'espace et l'espace construit la politique" (Dulucq \& Soubias 2004: 9).

9. My translation from French: "Il y a politique de l'espace parce que l'espace est politique" (Lefebvre 2000 [1974]). 
10. Similar declarations were also made during the Ugandan election campaign, notably by the FDC Presidential candidate, Dr. Kizza Besigye, who "decried the high cases of land grabbing in the sub-region, promising to end the vice once voted into power" (Saturday Monitor 2016). He further "pledged to return all grabbed land to owners" (Vision Group 2016). Even his opponent, Museveni "seeks to find solutions to historical land injustices in Uganda, land disputes and conflicts" (Ibid.).

11. See for example Peemans 2014, Ansoms et al. 2014; Martiniello 2015; Mollel 2014.

12. SUDECO was a parastatal company established in 1974, and is now the Sugar Board of Tanzania (SBT).

13. My translation from French: "Les courtiers du développement ne tombent pas du ciel. Ils sont le produit d'histoires locales, et fonctionnent à l'intérieur de réseaux."

14. My translation from French: “'Agriculteurs à tracteur'; ces fameux paysans modernistes chers au cœur de l'administration coloniale" (Martin 1988: 187).

15. My translation from French : "En tirer des bénéfices concernant l'accès au crédit, encore ; aux intrants agricoles ; à la terre, amorçant, malgré l'abolition de la propriété privée, des entreprises de concentration" (Martin 1988: 187).

16. My translation from French : "La création, en 1967, du Regional Development Fund, donne aux fonctionnaires/permanents les moyens de constituer des réseaux capables d'inclure les clientèles patronnées par des notables" (Martin 1988: 219).

17. My translation from French: "Un engrenage de niveaux de luttes factionnelles associant les citoyens, les notables, les responsables administratifs ou politiques nommés [ou élus] par le centre" (Martin 1988: 223).

18. My translation from French: "On a affaire à une coexistence de divers centres de pouvoir, d'importance et d'aire de compétence différentes, plus ou moins articulés, hiérarchisés ou concurrents, et relevant souvent de sédimentations historiques successives" (Olivier de Sardan 1995: 165).

19. My translation from French: "Il faut redire que ce sont bien les principes du développement qui ont renforcé la coercition administrative et technique du monde rural. (...) L'idéologie du développement implique un projet sur la nature, l'espace et la société. L'idée principale est que la nature est un capital donné (les fameuses 'ressources naturelles'); exit le fait que cette 'nature' est ou était déjà ordonnée, médiatisée et socialisée au sein de l'organisation des sociétés 'indigènes"' (Charlery de la Masselière $2014:$ 42).

20. My translation from French: “Tous [notables/fonctionnaires] sont 'modernistes', ambitieux, ouverts sur le monde extérieur, intéressés par la politique: ils peuvent parler ensemble, ils ont des langages communs" (Martin 1988 : 220).

21. Since the privatization of the Kilombero Sugar Company, the villages surrounding the plantation have been rapidly urbanized and people arriving from outside the valley continue to invest in land and infrastructure facilities, attracted by the sugar cane market. The main crop grown is sugar cane and most of the previous food crops (rice, maize, cassava) have been uprooted. 
INDEX

Keywords: land, SAGCOT, Kilombero, 2015 election campaign, voting

Geographical index: Tanzania | Tanzanie

\section{AUTHOR}

ADRIANA BLACHE

LISST-Dynamiques Rurales, University of Toulouse II - Jean-Jaurès, Toulouse, France. adriana.blache@gmail.com 